\title{
Modification of controlled hypotension induced by nicardipine or nitroprusside in cats pretreated with injectable acetyl salicylic acid
}

\author{
By \\ Mona M. Radwan \\ Department of Pharmacology, Faculty of Medicine for Girls \\ Al-Azhar University, Egypt
}

\begin{abstract}
:
Controlled hypotension is a well established technique to decrease blood loss and improve surgical visibility. Several different pharmacologic agents have been used for controlled hypotension including direct acting vasodilators such as sodium nitroprusside and calcium channel blockers (Testa and Tobias, 1995). This study was designed to assess the effect of non-steroidal anti-inflammatory drug (NSAID) acetyl salicylic acid (ASA) therapy on the efficacy and safety of I.V. infusion of nicardipine compared with the more commonly used agent; sodium nitroprusside. The effect of each drug on blood pressure and ECG pattern of normal"control" cats and cats pretreated with (ASA) was investigated. A target mean arterial pressure (MAP) of 55-65 $\mathrm{mmHg}$ was to be achieved.

It was found that both nicardipine and nitroprusside achieved a stable controlled hypotensive state in control groups. Comparison between the two drugs revealed a significant increase in (MAP) with nitroprusside after drug discontinuation. Pretreatment with (ASA), attenuated significantly the effect of nicardipine infusion on (MAP) . However, pretreatment with ASA produced insignificant effect on the decrease in MAP caused by nitroprusside except at $4 \mathrm{~min}$. during infusion where ASA pretreatment attenuated its effect. Moreover (ASA) pretreatment decreased nitroprusside dose needed to reach the target blood pressure and increased time of blood pressure to returin to base line.

Both nicardipine and nitroprusside infusion caused increase in mean heart rate (HR) without ECG changes in control and pretreated groups.There was a Statistically significant increase in (HR) in the (ASA) pretreated groups of both drugs when compared to that in the control groups. When the increase in (HR) induced by nitroprusside infusion was compared to that induced by nicardipine infusion, there was insignficiant difference in the control groups, while in (ASA) pretreatred groups the difference was significant.
\end{abstract}

\section{INTRODUCTION:}

One of the commonly used technique to limit blood loss and the possibility of transmitting infectious diseases in orth -opedic surgical procedures is controlled hypotension. Controlled hypo -tension; referred to as delibrate or induced hypo -tension, is defined as a lowering of mean arterial pressure (MAP) below $55 \mathrm{mmHg}$ or a decrease in (MAP) by one third or more from baseline values (Yaster et al., 1986). They used (MAP) as the determinant of the level of hypotension because it sets the lower limit of 
autoregulation in most organs, particularly the brain. Cont -rolled hypo -tension, is usually achieved by the use of a potent vasodilator with pred ictable, easily reversible effects. Sodium nitroprusside, is often used for this purpose despite the potential disa dvantages of cyanide toxicity, reflex tachycardia, and rebound hypertension (Bloor et al., 1985) . Nicardipine is an intravenously administered dihydropy ridine calcium channel antagonist. Its primary physiologic action is arterial vasodilation with limited chronotropic, dromotropic, and ionotropic effects (Frishman, 1989). Its distribution and elimination half life is short and this allow for rapid titration of blood pres sure ( Turlapaty et al., 1989 ).

During the past 25 years, (NSAIDs), have become one of the most frequently prescribed classes of medication. Concurrent use of (NSAIDs), in non arthritis conditions for both short and long term, may approach million of patients ( Houston,l99l).

Recently, there has been a growing awareness and concern that most of (NSAIDs) are additionally capable of affecting blood pressure (Klassen et al., 1995). So, this work was designed to assess and evaluate the effect of pretreatment with (ASA), on controlled hypotension induced by nicardipine or nitroprusside.

\section{MATERIALS AND METHODS}

Drugs used in this study were : nica -rdipine hydrochloride (Cardene, I.V.I, Syntex U.S.A), sodium nitropr -usside dihydrate (Nipride I.V.I, warwick U.K. "Sensitive to light"), and

acetyl salicylic acid ( Aspegic injec table, Amriya).

Doses corresponding to human thera -peutic doses were calculated according to the method reported by
Paget and Barnes (1964), and statistical analysis of the data was performed by student " $t$ " test of significance.

Mean arterial pressure $(\mathrm{MAP})=$ diastolic $+($ systole-diastol $) / 3 \mathrm{mmHg}$. Heart rate ( beats/min) was also calcu lated from the recorded ECG.

\section{Experiment design:}

Four groups of cats, each of six animals were used. The first group was treated with intravenous infusion ( I.V.I.) of nicardipine $(10 \mathrm{ug} / \mathrm{kg} / \mathrm{min}$.), and the second group with I.V.I. of sodium nitroprusside ( $\mathrm{lug} / \mathrm{kg} / \mathrm{min}$.). Both infus -ions were titrated as needed to ach -ieve the target (MAP) of 60 $\mathrm{mmHg}$ (55-65 $\mathrm{mmHg})$. Information collected for both drugs included (MAP) before, during, at the end of infusion, and after 10,20 mins. Of drug discontinuation. Drug requirement ( $\mathrm{ug} / \mathrm{kg}$ ), and the time needed for B.P. to return to baseline values were also recorded. ECG ( lead II) at baseline before hypotension, dur -ing the B.P. of $55-65 \mathrm{mmHg}$, and $20 \mathrm{~min}$. after drug discontinuation, was recorded. These two groups were consi -dered as control groups.

The third and fourth groups were pretreated with acetyl salicyclic acid (Aspegic I.M.) $25 \mathrm{mg} / \mathrm{kg} /$ day for 7 days. At the end of treatment period, animals in the third group were given nicardipine, and the fourth group were given nitroprusside in the same way mentioned in the first and second groups. The same parameters mentioned above were recorded and compared with that of the control groups.

\section{RESULTS:}

I. Effect of the drugs on mean arterial blood pressure (MAP) :

Control groups: Both nicardipine and nitroprusside infusion induced a drop in the MAP. Comparison between the effect of the two drugs revealed a 
significant increase in (MAP) with nitroprusside after drug infusion discontinuation compared to that with nicardipine infusion (Figs 1,2, Table 1).

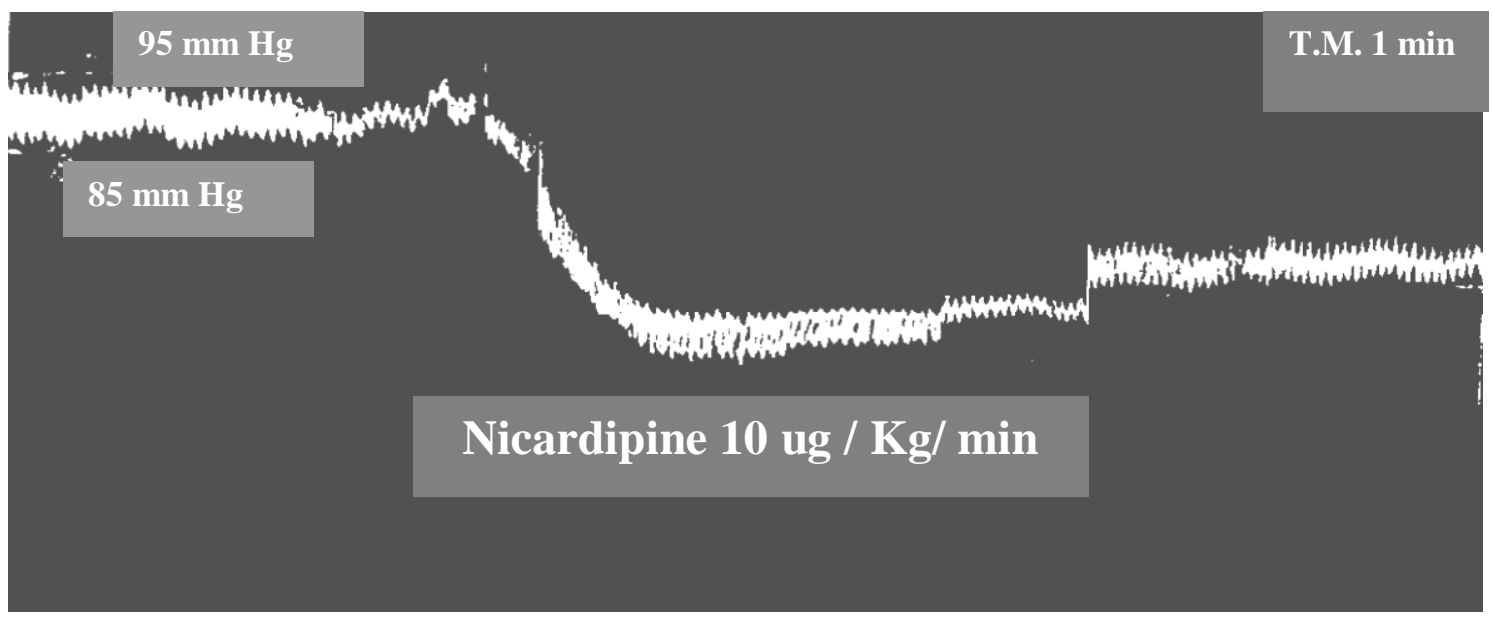

Fig. (1): Controlled hypotension induced by nicardipine $10 \mu \mathrm{g} / \mathrm{kg} / \mathrm{min}$. infusion in control cats.

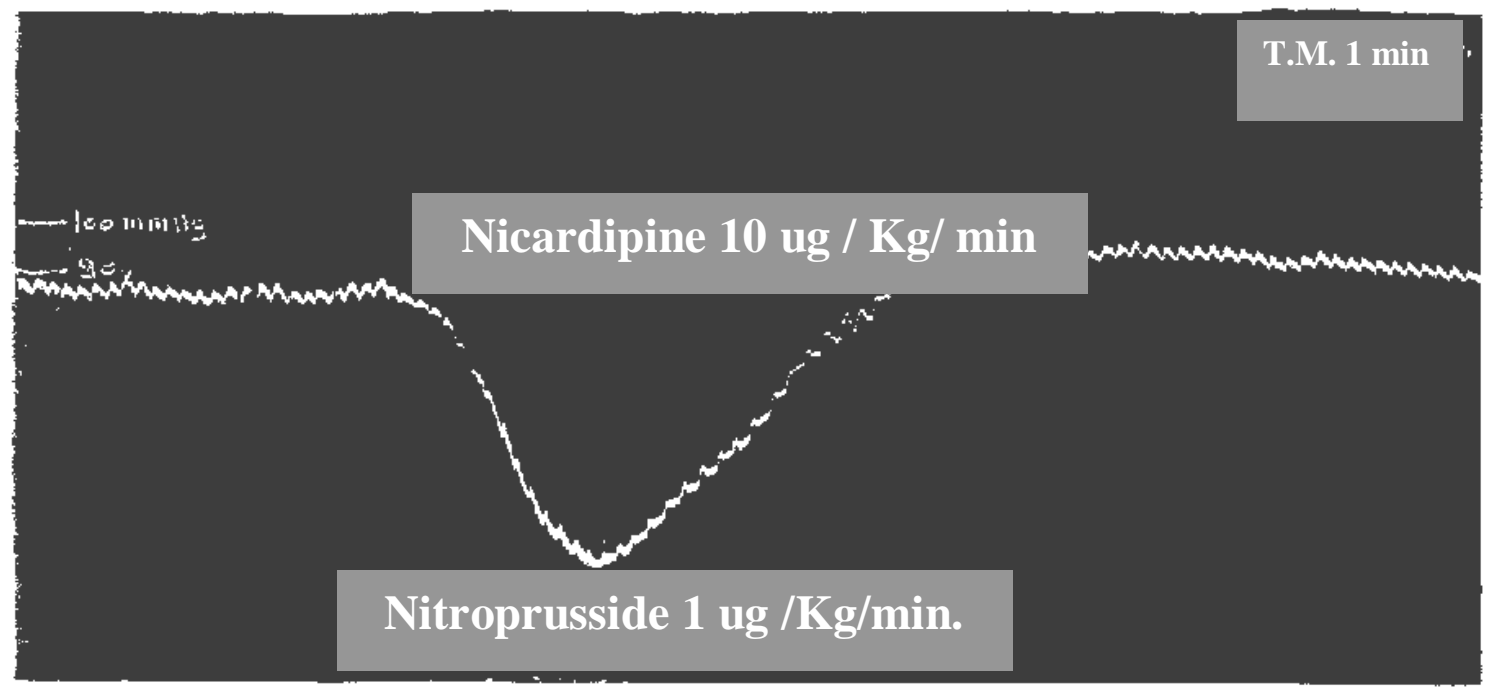

Fig. (2): Controlled hypotension induced by nitroprusside $1 \mu \mathrm{g} / \mathrm{kg} / \mathrm{min}$. infusion in control cats.

\section{Acetyl salicylic acid pretreated} groups: Pretreatment with (ASA) attenuated the effect of nicardipine on (MAP). This attenuation was statist ically significant, compared to that of control group. Comparison between the effect of nicardepine and nitroprusside infusions in (ASA) pretreated groups, showed a statistically significant dec rease in (MAP) with nitroprusside during and at the end of infusion (Figs. 3,4, Table 1). 


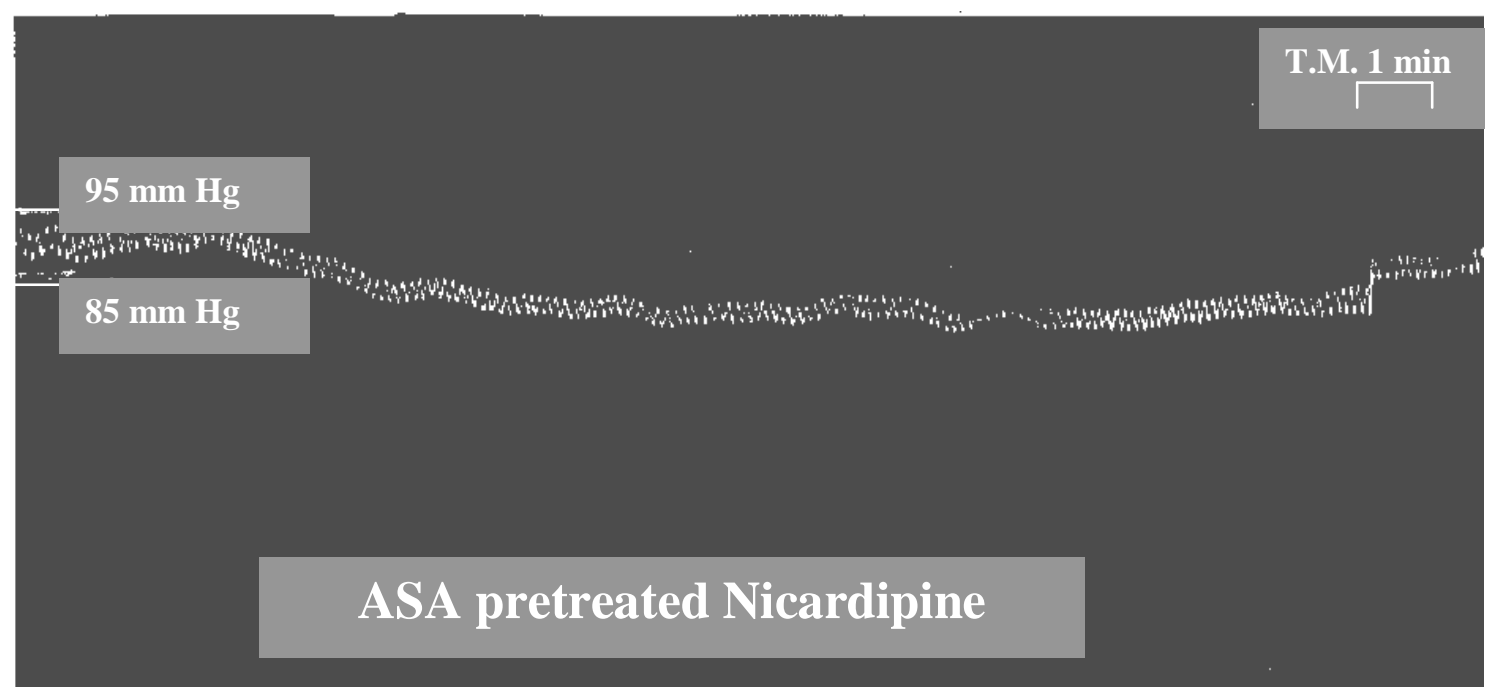

Fig. (3): Controlled hypotension induced by nicardipine $10 \mu \mathrm{g} / \mathrm{kg} / \mathrm{min}$. infusion in ASA pretreated cats.

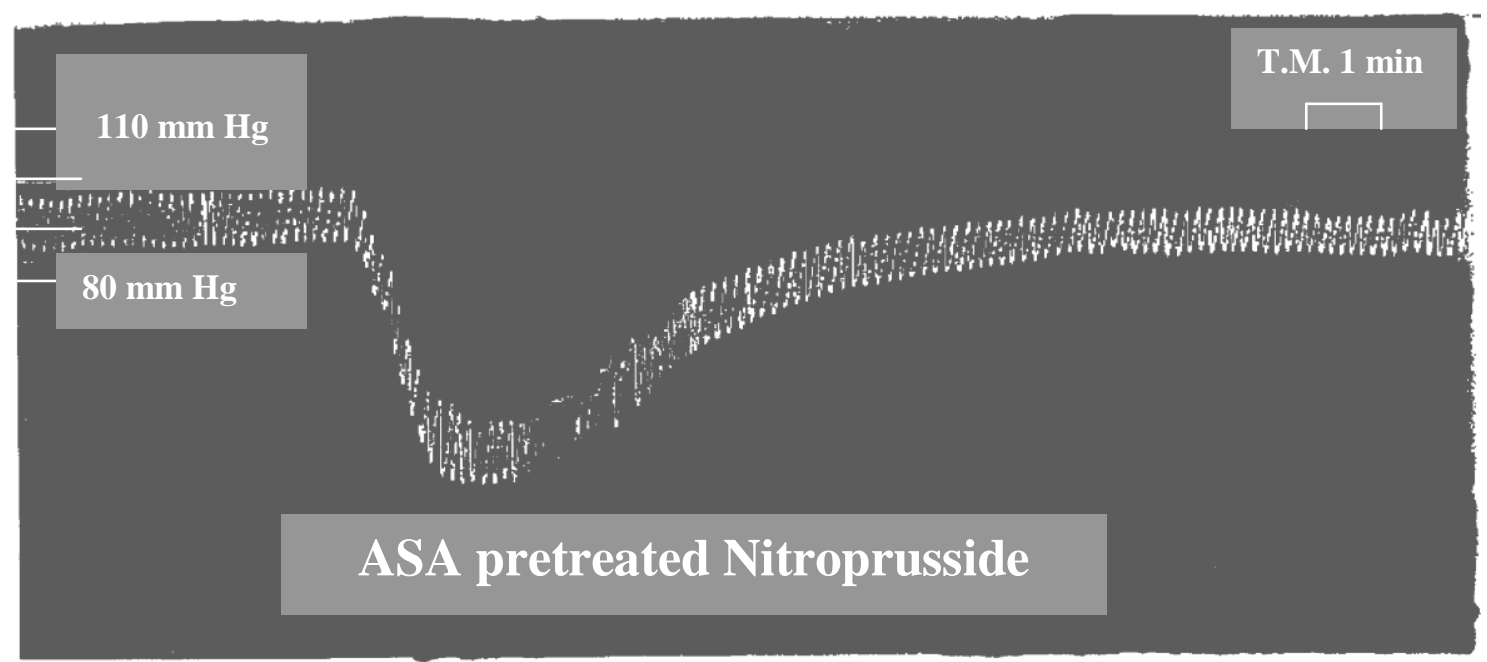

Fig. (4): Controlled hypotension induced by nitroprusside $1 \mu \mathrm{g} / \mathrm{kg} / \mathrm{min}$. infusion in ASA pretreated cats. 


\section{Mona M. Radwan}

Table (I): Effect of pretreatment with acetyl salicylic acid ( Aspegic I.M. $25 \mathrm{mg} / \mathrm{kg} /$ day for 7 days) on controlled hypotension induced by nicardipine ( $10 \mathrm{ug} / \mathrm{kg} / \mathrm{min}$.) or nitroprusside ( I ug/kg/min) infusion.

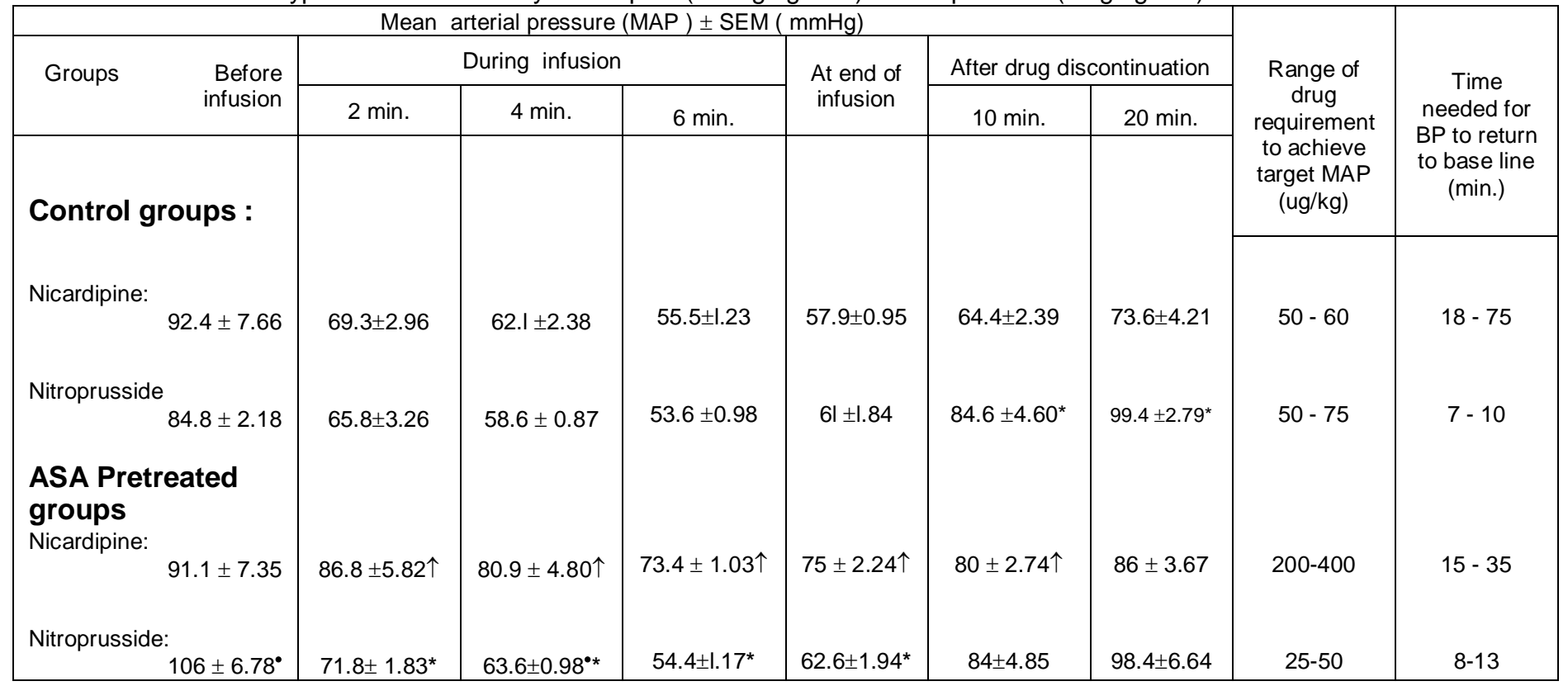

* Significant difference between the effect of nitroprusside and nicardipine in control and (ASA) pretreated groups.

$\uparrow$ Significant difference in the effect of nicardipine in (ASA) pretreated group when compared to that in control group.

-Significant difference in the effect of nitroprusside in (ASA) pretreated group when compared to that in control group.

\section{Effect of drugs on ECG:}

Reflex increase in mean heart rate ( HR) , without ECG changes was seen with both drugs in control and ( ASA) pretreated groups (Table 2). There was a statistically significant increase in (HR) in the (ASA) pretreated groups when compared to that in the control groups. The increased (HR) with nitroprusside infusion was statistically insignificant $(\mathrm{P}>0.05)$ in control group and significant in (ASA) pretreated group when compared to that with nicardipine infusion.

Table (2): Effect of pretreatment with acetyl salicylic acid ( Aspegic IM $25 \mathrm{mg} / \mathrm{kg} /$ day $/ 7$ days). On heart rate (HR) beats $/ \mathrm{min}$ (mean \pm SEM) caused by nicardipine (10 ug/ $/ \mathrm{kg} / \mathrm{min}$.) or nitroprusside ( $1 \mathrm{ug} / \mathrm{kg} / \mathrm{min})$ infusion.

\begin{tabular}{|c|c|c|c|}
\hline Groups & Initial (HR) & $\begin{array}{c}\text { (HR) during target mean } \\
\text { arterial pressure }\end{array}$ & $\begin{array}{c}\text { (HR) after } 20 \text { min of drug } \\
\text { discontinuation }\end{array}$ \\
\hline \multicolumn{4}{|l|}{ Control group } \\
\hline Nicardipine & $160 \pm 7.07$ & $177 \pm 7.07$ & $177 \pm 7.07$ \\
\hline Nitroprusside & $160 \pm 7.07$ & $200 \pm 7.07$ & $177 \pm 7.07$ \\
\hline \multicolumn{4}{|l|}{ (ASA) pretreated groups: } \\
\hline Nicardipine & $200 \pm 7.07 *$ & $228 \pm 7.07 *$ & $228 \pm 7.07 *$ \\
\hline Nitroprusside & $228 \pm 7.07 \uparrow \bullet$ & $266 \pm 7.07 \uparrow^{\bullet}$ & $228 \pm 7.07 \uparrow$ \\
\hline
\end{tabular}

* Significant difference between the effect of nicardipine in (ASA) pretreatment group when compared to that in ontrol group. $\uparrow$ Significant difference between the effect of nitroprusside in (ASA) pretreatment group when compared to that in control group.

- Significant difference between the effect of nitroprusside in (ASA) pretreatment group when compared to that of nicardipine pretreated group. 


\section{DISCUSSION:}

Because arthritis and hyperten sion are conditions that frequently occur together, there is a large popula tion of patients for whom the concurrent use of antihypertensive and NSAIDs is indicated. The NSAIDs attenuate the antihypertensive actions of most antih ypertensive drug classes. The effect on blood pressure can vary from none to severe blood pressure elevation, depe nding on the NSAIDs used (Pope et al., 1993). Such interactions are of great clinical importance given the widesp read use of NSAIDs and their " Over the -Counter" availability. Most often, hypotension is induced by a potent vasoactive agent with predictable short life and easily reversible effects. For these reasons, nitroprusside remains very desirable although there is a risk of cyanide poisoning at doses $>1.5$ $\mathrm{mg} / \mathrm{kg}$ (Michen -felder and Tinker, 1977). Short-term infusion of nicardipine; a water-soluble photoresis -tant dihydropyridine calcium channel blocker, also can be used to induce deliberate hypotension (Bernard et al., 1991).

The present study showed that the control groups receiving nicardip ine and nitroprusside allowed a rapid achievement of hypotension. After discontinuation of the infusions nitrop -russide induced a statistically signific ant increase in MAP and rapid recovery in comparison to nicardipine. This action shows conformity with the study of Bernard et al. (l99l) who reported that, nicardipine was, as potent and as easy to use as nitroprusside in reducing arterial blood pressure. He also reported that repound hypertension was observed after abrupt discontinuation of nitropru sside, resulting from persistent increa sed plasma renin activity and catecho lamine levels. Tobias e tal., (1996) also mentioned that, blood pressure rapidly returned to base line after nitrop -russide discontinuation and a more prolonged effect was noted with nicard ipine. The authors suggested that, the prolonged vasodilatory effect of nicardi -pine might be efficacious in that it prevented the rebound hypertension related to the elevated plasma renin activity and endogenous catecholamines that is sometimes seen with nitropr usside infusion. A possible explanation of the difference in time courses of the two drugs may also be found in their cellular mechanisms of action. Nitroprusside causes vascular relaxation via production of nitric oxide (NO), which has a half-life of 0.1 seconds . Removal of this (NO) donor would be expected to cause rapid restoration of BP (Hersey et al., l997) Nicardipine, however is a calcium channel blocker, and it interferes with calcium dependent regulatory mechanism of vascular smo -oth muscle tone. Removal of nicar ipine would not result in restoration of baseline BP until the drug diffuses off the receptor site and normal intra-and extracellular calcium balance is resto red ( Dzau et al., 1993).

Pretreatment with (ASA), in the present study, attenuated significantly the effect of nicardipine infusion on (MAP) .However, nitroprusside infus ion caused a decrease in the (MAP), which was statistically significant comp -ared to that of nicardipine effect. The proposed mechanism for NSAIDs atten -uation of blood pressure effect, is relat -ed to blockade of cyclooxygenase path -way of aracidonic acid metabolism with a resultant decrease in the biosynt hesis of all prostanoids (Pope et al.,l993). The prostaglandins are impo rtant in normal modulation of renal, glomerular and systemic vascular dilatation and sodium water balance 
(Patrono and Dunn, 1987). Inhibition of this system by NSAIDs may lead to renal vasoconstruction, reduction in glomerular filtration rate, increase in sodium and water resorption, intrava scular volume over load, enchanced adrenergic neurotransmission, increa sed effects of angiote nsinII, and vasopressin, and increased intravasc ular volume with increased systemic vascular resistance, resulting in substantial elevation in blood pressure Unless the antihypertensive drug maint -ains its efficacy in the presence of such changes (Houston et al., 1995). Recently, Foegh and Ramell (200l) reported also that, prostaglandin synth ase (cyclooxygenase) is not needed for the formation of isoprostanes; prosta glandin stereoisomers. The importance of this pathway lies in the large amounts of these products, and their potent vasoconstrictor effects in the vascular beds. The same authors found that aspirin should not affect the isoprostane pathway.

Calcium channel blockers are known to have direct vasodilatory effects on resistance vessels and this is likely their major antihypertensive mechanism. They also have clearly shown that they have a natriuretic effect ( Weinberger, 199l). This natriur etic peptides, have a short half-life in the circulation as reported by Levin et al.(l998). Despite of this natriuresis Houston et al., (1995) found that, the NSAIDs; ibuprofen and naproxen, in concomitant use with sustained release verapamil hydrochloride, increased blood pressure significantly. Klassen et al., (l995) stated insignificant increase in blood pressure when naproxen was added to nicardipine therapy. A few clinical reports, on the other hand, have suggested that NSAIDs, do not attenuate the antihypertensive effects of calcium channel blockers (Houston, 199l).

The failure of NSAIDs to compete with nitroprusside effect on blood pressure was explained by the varying effects of these antihypertensive agents. Nitroprusside causes vascular relaxation via production of nitric oxide which results in increased cGMP synthesis and smooth muscle relaxation (Bernard et al., 199l). Direct vasodila tion due to nitroprusside may compete with vasoconstriction produced by ASA increasing autonomic activity, catec holamine secretion, and angiotensin II activation (Knight et al.,l983). In addition, it may be explained by arterial and venous effects of nitroprusside in contrast to the vasodilatory effect of nicardipine which is most probably an arterial effect (Bernard et al., 199l).

With regards to the effect of both nicardipine and nitroprusside infusions on the ECG of cats, both drugs exhibited reflex increase in mean heart rate without changing the ECG pattern. This increase was statistically signif icant in (ASA) pretreated groups receiv -ing nicardipine or nitropruside in comp -arison to control groups receiving the same drugs. The increased heart rate due to nitroprusside was higher than that due to nicardipine in control (insig -nificant) and in (ASA) pretreated (significant) groups. This tachycardia can be explained by an acute activation of the baroreflex control mechanism, which follows the blood pressure and buffers it around the new level of set point ( Young et al.,l984) . Previous reports have indicated that, nicardipine results in less reflex tachycardia than nitroprusside ( The IV nicardipine study group, 199l). Hersey et al. (l997) reported also that, although more patients in the nitroprusside group required esmolol, the reflex 
tachycardia was not statistically significant. Studies in adults comparing nicardipine with nitroprusside for intraoperative and postoperative hypertension, demonst -rated also a significant smaller increasae in heart rate with nicardipine than with nitroprusside ( Halpern et al., 1992) . The positive chronotropic pattern of (ASA) pretreated groups, seems to be due to the vasoconstriction produced by (ASA) increasing auton -omic activity, catecholamine secretion and angiotensin II activation as previously explained by Knight et al., (1983).

In this study it was concluded that, controlled hypotension can be easily achieved by nicardipine infusion. Moreover there is a beneficial slow gradual return to baseline blood press ure in comparison to the rebound hyper -tension and reflex tachycardia induced by nitroprusside infusion. Non steroidal anti-inflammatory "acetylsalicylic acid" regimens, used in this study attenuated significantly the hypotensive effect caused by nicardipine . Nitroprusside was Uniformly effective. In addition (ASA) pretreatment decreased nitropr -usside dose needed to reach the target blood pressure, and increased the time needed for the blood pressure to return to baseline. Therefore, nitroprusside appears to be the agent of choice for rapid induction of controlled hypot -ension in Patients who are taking Concomitant long-term acetylsalicylic acid therapy.

\section{REFERENCES :}

1. Bernard J.M.; Pinaud M.; Francois T.; Babin M.; MacquinMavier I. and Letenneur J. (199l): Deliberate hypotension with Nicar dipine or Nitroprusside During total Hip Arthroplasty. Anesth. Analg.; 73: 341-5.
2. Bloor B.C.; Fukunaga A.F.; Mac et al. (1985): myocardial hemo -dynamics during induced hypote nsion: a comparison between sodi um nitroprusside and adenosine Trip -hosphate. Anesthesiology; 63: 517-25.

3. Dzau V.J. ; Cooke J.P. and Tsao P.S. (l993): $\quad$ Cellular mechanisms of vasodilatation in: O'Rourke M.; Safar M. Dzau, eds. Arterial vasodi -latation: Mechanisms and therapy. Philadelphia: Lea \& Febiger: 201.

4. Foegh M.L and Ramwell P.W. (200l) : The Eicosanoids: Prostagla -ndins, Thromboxanes, Leukotrienes, and related Compounds. IN Basic and Clinical Pharmacology. Edited by Katzung BG; eighth edition, Chap 18; p. 311325 ; Appelton and Lange, California.

5. Frishman W.H. (l989): New therapeutic modalities in hyperte nsion: Focus on a new calcium ant agonist-nicardipine. J. Clin. Pharma -col.; 29 : 481-7.

6. Halpern N.A.; Goldberg M. Neely C. et al. (1992): posto perative hypertension: a multicenter, prospective, randomized compar ison between intravenous nica rdipine and sodium nitrop -russide. Crit. Care Med. 20: 1637-43.

7. Hersey S.L., O'Dell N.E.; Lowe S.; Rasmussen G.; Tobias J.D.; Deshpande J.K.; Mencio G., and Green N. (1997): Nicardipine versus nitropressure for Controlled hypoten -sion during Spinal Surgery in Adolescents . Anesth Analg.; 84: 1239-44.

8. Houston M.C. (l99l): Nonster -oidal anti-inflammatory drugs and antihypertensives. Am. J. Med.; 90 (Suppl. 5A) : 42S-47S. 
9. Houston MC, Weir M.; Gray J.; Ginsberg D. ; Szeto C.; Kaihlenen P.M.; Sugimoto D.; Runde M. and Lefkowitz M. (1995) : The effects of Nonsteroidal antiinflammatory drugs on blood pressures of Patients with Hypertension Controlled by Verapamil. Arch. Intern Med.; 155: 1049-1054.

10. Klassen D.K.; Jane L.H. ; Young D.Y. and Peterson C.A. (1995): Assessment of blood press -ure during Naproxen therapy in hypertensive patients treated with nicardipine, Am. J. of Hypertension; 8: 146-153.

11. Knight P.r.; Lane G.A.; Hensinger R.N.; Bolles R.S. and Bjoraker D.G. (l983): Catecho lamine and Renin-Angiotensin response during hypotensive anest hesia induced by sodium nitropru sside or Trimethaphan Camsylate. Anesthesiology; 59: 248-253.

12. Levin E.R.; Gardner D.G. and Samson W.K. (1998): Mechanisms of disease: Natriuretic peptides. N. Engl. J. Med.; 339: 321.

13. Michenfelder J.D. and Tinkr J.H. (1977): Cyanide toxicity and thiosulfate protection during chronic administration of sodium nitroprus side in the dog: Correlation with a human case. Anesthesiology; 47: 441-8.

\section{Paget GE and Barnes J.M.}

(1964): Toxicity test. In: Evaluation of drug activities, Pharmacometrics. Edited by Laurence DR and Bacha rach AL; Vol. I ; Chap. 6; P. 135; Academic Press; London and New York.

15. Patrono C. and Dunn M.J. (1987): The clinical significance of inhibition of renal prostaglandin synthesis. Kidney Int.; 32: 1-12.
16. Pope J.E.; Anderson J.J. and Felson D.T. (1993): A metaanalysis of the effects of nonsteroidal anti-inflammatory drugs on blood pressure. Arch Intern. Med.; 153: 477-484.

17. Testa L. and Tobias J.D. (1995): Pharmacologic agents for controlled hypotension. J. Clin. Anesth.; 7: 326-37.

18. The IV Nicardipine, study group (l99l): Efficacy and safety of intrav -enous nicardipine in the control of postoperative hypertension. Chest.; 99: 393-8.

19. Tobias J.D.; Hersey, S.; Mencio G.A. and Green N.E. (l996): Nicardipine for controlled hyportens -ion during spinal surgery. J. Pediatr. Ortho.; 16, No. 3: 370-373.

20. Turlapaty P.; Vary R.; and Kaplan J.A. (1989): Nicardipine, a new intravenous calcium antagonist: A review of its pharmacology, Pharmacokinetics, and Preoperative applications. J. Cardiothorac. Anes -th.; 3: 344-55.

21. Weinberger M.H. (l99l): The relationship of sodium balance and concomitant diuretic therapy to blood pressure response with calcium channel entry blockers. Am. J. Med.; 90 (suppl. 5A) : 15 S$20 \mathrm{~S}$.

22. Yaster M.; Simmons R.S.; Tolo V.T.; Pepple J.M. ; Wetzel; R.C. and Rogers M.C. (1986): A comparison of Nitroglycerin and Nitroprusside for inducing hypotension in children: A Doubleblind study. Anesthesiology 65: 175-179.

23. Young M.A.; Watson R.D.S. and Littler W.A. (1984): Baroreflex setting and sensitivity after acute and chronic nicardipine therapy, Clinical Scie; 66, 233-235. 
التحوير فى خفض الضـظط المقنَّن المُحدَّث بواسطة النيكارديبين أو الصوديوم نيترويروسيد فى القطط المُسَّبق معالجتها بحقن حمض الأستيل ساليسيلك

\author{
منس محمد رضوان \\ قسم الفارماكولوجى - كلية طب البنات \\ جامعة الأزهر - القاهرة
}

أُجرى هذا البحث لمعرفة تأثنير حمض الاستيل ساليسيلك على فاعليـة النيكاردييين أو

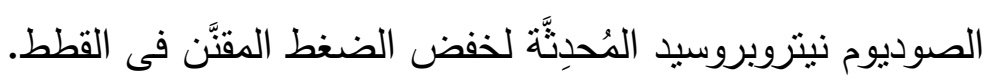

استخلص من هذا البحث أن خفض الضغط المقَّنن ممكن إحداثه بطريقة سهلة بواسطة

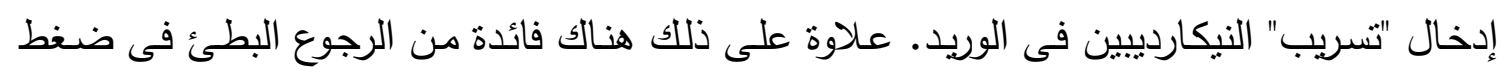

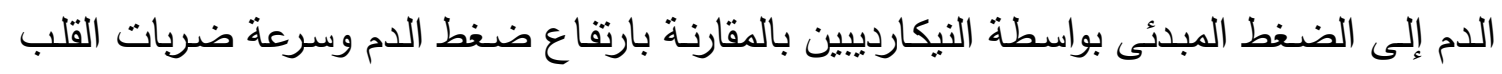
اليُحدثة كرد فعل لاستخدام النيتروبروسيد.. وذلك فى القطط المستخدمة كمرجع.

أما عند حقن حمض الاستيل ساليسيلك المسُبق لاستخدام النيكارديبين أو النيتروبروسبد..

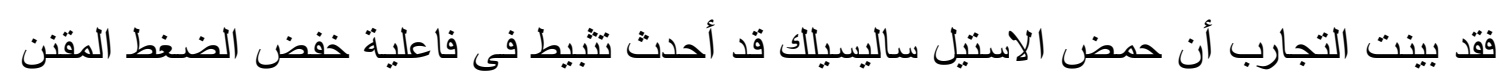

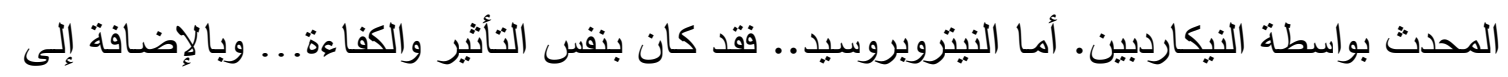
ذلك فقد حدث خفض فى كمية النيتروبروسيد المطلوبة للوصول إلى الضغط المنخفض... وكذلك حدث زيادة فى الوقت المطلوب للعودة بضغط الدم إلى المستوى المبدئى. من هذا يتضح أن الصوديوم نيتروبروسيد هو الدواء المطلوب لإحداث خفض ضغط دم مقنَّن وذو فاعلية فى الحالات التى سبق استخدامها لحمض الاستيل ساليسيلك. 